UCRL-CR-122614

B291561

\title{
Long-Term Results from Unsaturated Testing of Actinide-Doped DWPF and WVDP Waste Glasses
}

J.A. Fortner

J.K. Bates
RECEIVED

MAR 181996

OSTI

November 1995

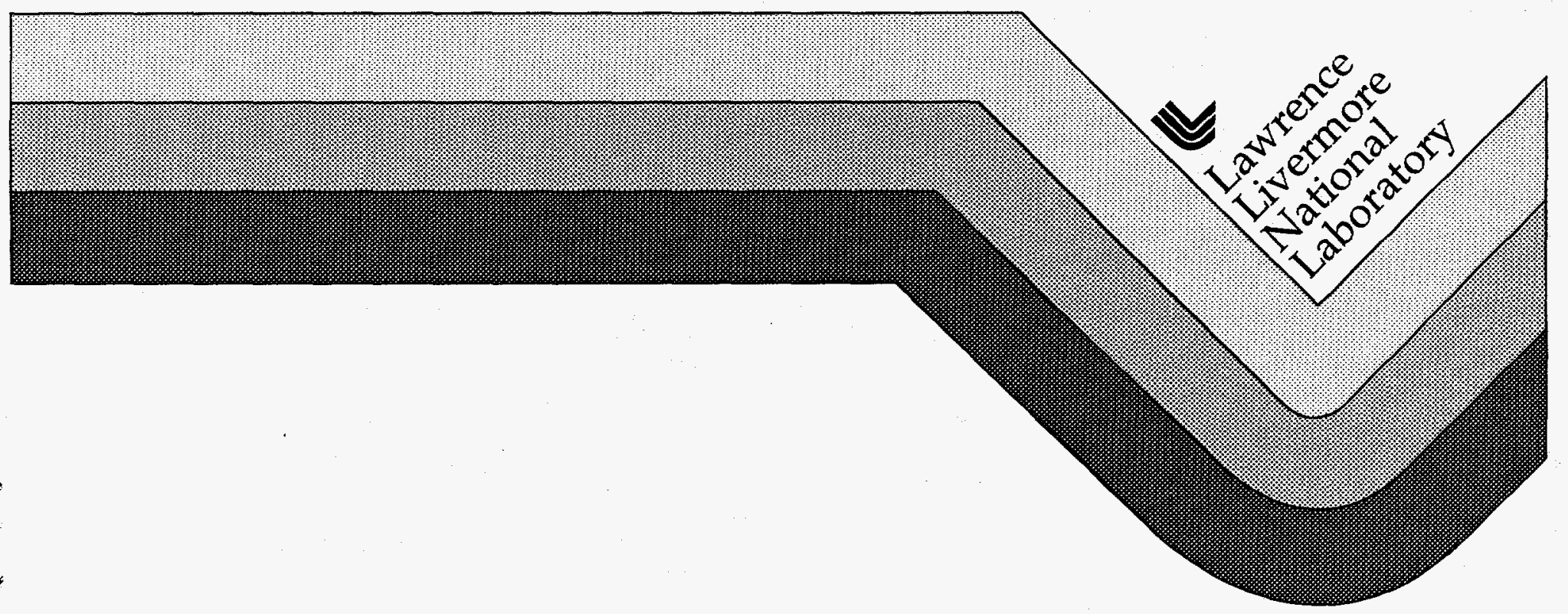




\section{DISCLAIMER}

This document was prepared as an account of work sponsored by an agency of the United States Government. Neither the United States Government nor the University of California nor any of their employees, makes any warranty, express or implied, or assumes any legal liability or responsibility for the accuracy, completeness, or usefulness of any information, apparatus, product, or process disclosed, or represents that its use would not infringe privately owned rights. Reference herein to any specific commercial products, process, or service by trade name, trademark, manufacturer, or otherwise, does not necessarily constitute or imply its endorsement, recommendation, or favoring by the United States Government or the University of California. The views and opinions of authors expressed herein do not necessarily state or reflect those of the United States Government or the University of California, and shall not be used for advertising or product endorsement purposes. 


\title{
LONG-TERM RESULTS FROM UNSATURATED TESTING OF ACTINIDE-DOPED DWPF AND WVDP WASTE GLASSES
}

\author{
J. A. Fortner and J. K. Bates \\ ARGONNE NATIONAL LABORATORY \\ Chemical Technology Division \\ 9700 South Cass Avenue \\ Argonne, IL 60439-4837
}

The submitied manuscript has been
authored by a contractor of the U.S.
Government under contract No. W-31-108-
ENG-38. Accordingly, the U.S. Govemment
retains a nonexclusive, royalty-free license
to publish or reproduce the published form of
this contribution, or allow others to do so, for
U.S. Government purposes.

Submitted to

Materials Research Society

Boston, MA

November 27-December 1, 1995 


\section{LONG-TERM RESULTS FROM UNSATURATED DURABILITY TESTING OF ACTINIDE-DOPED DWPF AND WVDP WASTE GLASSES}

Jeffrey A. Fortner and John K. Bates, Argonne National Laboratory, Argonne, IL 60439, USA.

\section{ABSTRACT}

Results from durability drip tests designed to simulate the unsaturated conditions in the proposed Yucca Mountain Repository are reported for two actinide-doped glasses used as model waste forms. These tests are being conducted with reference glass compositions doped with neptunium, plutonium, and americium from the Defense Waste Processing Facility (DWPF) and the West Valley Demonstration Project (WVDP), and have been ongoing for over 8 years. Solution compositions, including transuranics, have been periodically determined, and selected analyses of colloid formation and composition, glass corrosion layers, and solid alteration phases have been obtained by scanning and analytical transmission electron microscopies. The importance of integrated testing has been demonstrated, as complex interactions among the glass, the groundwater, and the sensitized stainless steel have been observed. The cumulative releases of both glassforming and dopant elements are presented along with identification of reaction phases and their partitioning between solution and solid phases. Alteration phases, including smectite clay, iron silicates, uranium silicates, and calcium thorium phosphate, have been observed forming on the glass and stainless steel and have occasionally been found suspended in solution as colloids. Actinides, except neptunium, concentrate into alteration phases or sorb onto the stainless steel. The subsequent transport of the actinides is then controlled by these phases.

\section{INTRODUCTION}

The first Unsaturated Glass Durability Tests (N2 series) to be initiated were on actinide- and technetium-doped Defense Waste Processing Facility (DWPF) SRL 165 glass, which were begun in February 1986. These tests are still in progress and glass and solution samples have been analyzed intermittently over the ensuing period of nearly nine years. The N3 series of Unsaturated Durability Tests, performed on actinide- and technetium doped West Valley Demonstration Project (WVDP) ATM-10 glass, were begun in July 1987. The ATM-10 glass is a former reference glass for the WVDP and its composition differs only slightly from the present West Valley reference glass, WV6.

The objective of the $\mathrm{N} 2$ and $\mathrm{N} 3$ durability tests is to determine the reaction progress of waste glasses under conditions likely to exist at the Yucca Mountain geologic repository site in Nevada, should groundwater breach the engineered barrier system. Output from each test series includes the rate of glass reaction and radionuclide release as a function of time, a description of the distribution of radionuclides in solution (i.e., dissolved in solution, associated with colloidal material, or sorbed onto metal components of the test), and an examination of the interactions between the various components in the test. Ultimately, the results from these tests will be used to validate source terms of models used in waste package performance assessment codes.

\section{EXPERIMENTAL PROCEDURE}

In the Unsaturated Durability Tests, $0.075 \mathrm{~mL}$ (about 3 drops) of tuff-equilibrated groundwater from the J-13 well near Yucca Mountain (termed EJ-13 water) is dripped onto the simulated waste package in a sealed stainless steel test vessel every 3.5 days. The simulated waste package used in the tests consists of a cylindrical monolith of waste glass, approximately $16 \mathrm{~mm}$ diameter and $20 \mathrm{~mm}$ high, plus a holder made of perforated, sensitized $304 \mathrm{~L}$ stainless steel. The entire test apparatus is enclosed in a $90^{\circ} \mathrm{C}$ oven except when samples are taken and observations made.

Details of the experimental procedure and the compositions of the glasses used in the N2 and N3 Tests are given elsewhere [1,2]. The content of technetium and the actinides in the glasses is summarized in Table 1. The composition of the EJ-13 groundwater used in the tests is given in Table 2 for the most concentrated elements. The composition of the EJ-13 is measured at each test sampling and varies by $\sim 20 \%$ among batches for the major elements.

To appear in Materials Research Society Symposium on the Scientific Basis for Nuclear Waste Management XIX (1995). 
The tests are sampled periodically to monitor reaction progress. During each sampling, the simulated waste package is visually examined for evidence of reaction, then transferred to a clean test vessel pre-loaded with $0.5 \mathrm{~mL}$ of EJ-13 water and returned to the $90^{\circ} \mathrm{C}$ oven. Solution from the just-completed test is submitted for elemental analysis with inductively coupled plasma mass spectroscopy (ICP/MS) and radiochemical analysis with high-resolution alpha spectroscopy. If sufficient solution exists, sequential filtering is done, and the filters and filtrate solution are submitted for high resolution alpha spectroscopy. Since the 1993 samplings, colloidal material was also collected for examination by analytical transmission electron microscopy (AEM). After removal of the leach solution, the test vessel is then acid stripped to remove the remaining actinides. This acid strip solution is submitted for high-resolution alpha spectroscopy; since 1993, this solution has also been analyzed with ICP/MS.

Table 1. Compositions, in oxide weight percent, of the technetium and actinides in the glasses used in the $\mathrm{N} 2$ and $\mathrm{N} 3$ tests.

\begin{tabular}{lcl}
\hline Oxide & $\begin{array}{c}\text { N2 Tests } \\
\text { SRL 165 }\end{array}$ & $\begin{array}{l}\text { N3 Tests } \\
\text { ATM-10* }\end{array}$ \\
\hline $\mathrm{Tc}_{2} \mathrm{O}_{7}$ & 0.02 & 0.003 \\
$\mathrm{ThO}_{2}$ & - & 3.3 \\
$\mathrm{UO}_{2}$ & 0.92 & 0.53 \\
${ }^{237} \mathrm{NpO}_{2}$ & 0.008 & 0.02 \\
${ }^{239} \mathrm{PuO}_{2}$ & 0.022 & 0.008 \\
${ }^{241} \mathrm{AmO}_{2}$ & 0.0004 & 0.006 \\
\hline${ }^{8}$ From Bates and Gerding [1]. \\
${ }^{*}$ From Maupin et al. [6].
\end{tabular}

Table 2. Typical composition of the EJ-13 water used in the N2 and $\mathrm{N} 3$ tests.

\begin{tabular}{lc}
\hline Element & $\begin{array}{c}\text { Concentration } \\
(\mathrm{mg} / \mathrm{L})\end{array}$ \\
\hline $\mathrm{Al}$ & 1 \\
$\mathrm{~B}$ & 0.2 \\
$\mathrm{Ca}$ & 5 \\
$\mathrm{Fe}$ & 0.1 \\
$\mathrm{~K}$ & 7 \\
$\mathrm{Na}$ & 54 \\
$\mathrm{Si}$ & 45 \\
$\mathrm{NO}_{3}^{-}$ & 11 \\
$\mathrm{HCO}_{3}^{-}$ & 100 \\
\hline
\end{tabular}

In the discussion below, the solution collected in the test vessel that had contacted the waste package during the course of the test is designated the vessel rinse (VR) and the solution that results from soaking the vessel with acidified water is called the acid strip (AS). The total release is then the sum of the masses from the vessel rinse and acid strip solutions. As the glass reacts, material is released from the glass either truly dissolved in solution or as particulate material. The solution also contacts the pre-sensitized $304 \mathrm{~L}$ stainless steel retainer during the reaction process and the solution collected in the bottom of the test vessel contains all the material that is transported from the glass and glass retainer, but not that which remains with the retainer.

Since the December 1993 and January 1994 samplings of the N2 and N3 tests, respectively, small portions $(-5 \mu \mathrm{l})$ of the test solution have been wicked through a porous or "holey" carbon transmission electron microscope grid to allow AEM examination of suspended particles. The AEM is useful at magnifications in excess of $100,000 \mathrm{x}$ and also provides electron diffraction images, energy dispersive X-ray fluorescence spectroscopy (EDS), and electron energy loss spectroscopy. The AEM provides compositional and structural information of the particles trapped on the grid, but because of the small sample size, results from several test periods are required to substantiate conclusions.

\section{RESULTS}

\section{Solution Cation Analyses}

The results presented here update earlier reports of the release of material to solution $[1,3,4]$. The analytical results for the solid components through 1 year of testing has been given elsewhere $[1,5]$. To put the solution results into experimental context, we begin by discussing recent observations of the top surface of the N3\#10 sample. Figure 1 is an optical micrograph of 
this sample as it appeared during sampling in July, 1995, after about 8 years of testing. This is typical of the sample appearance in both the N2 and N3 tests. The surface of the glass is covered by an alteration layer of clay, with other alteration phases beneath and within the clay. As the clay becomes increasingly thick, it will pull away or "spall" from the surface of the glass, as can be seen in the figure. Fragments of this material, often along with other alteration phases, may then be swept into solution where they will either settle to the bottom of the test vessel or remain suspended as colloids, depending on particle size and solution conditions.

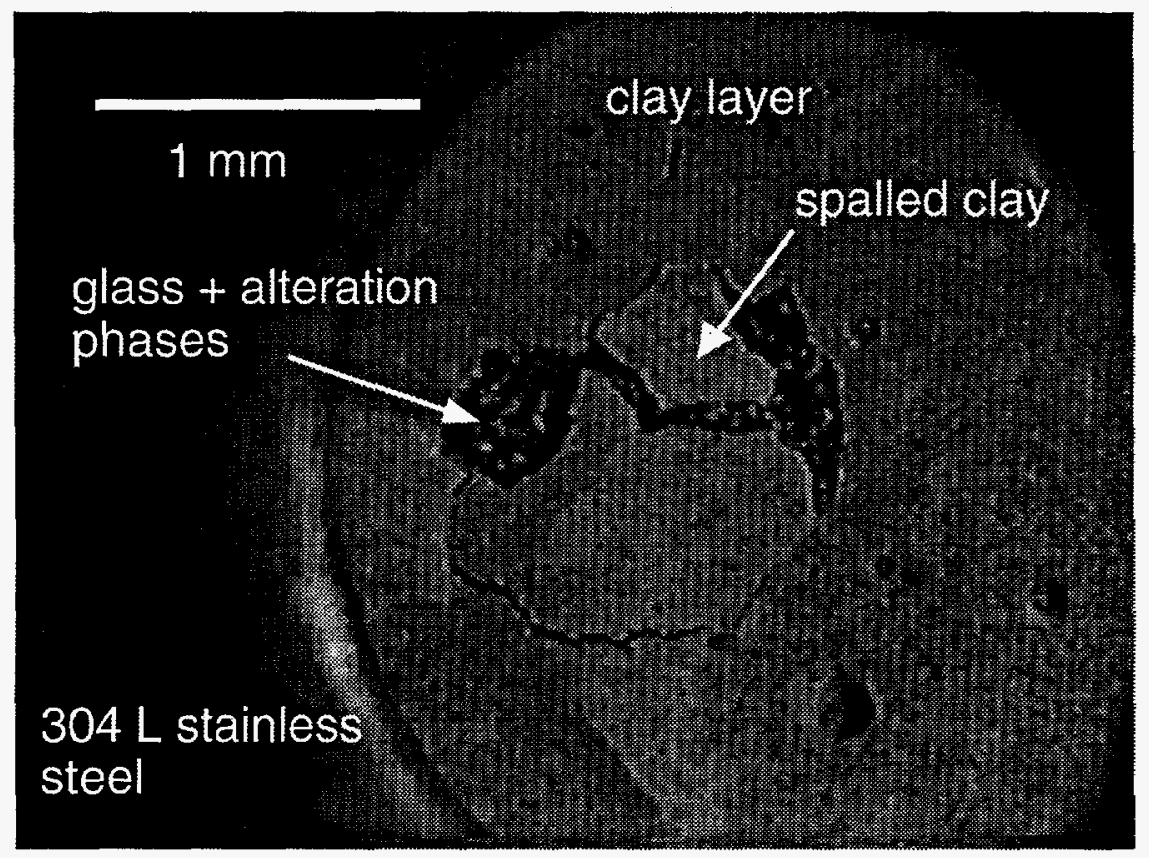

Figure 1. Optical image of the top surface of the N3\#10 waste package after 418 weeks of testing. The perforated stainless steel holder (representing a compromised pour canister) and the actinide-doped ATM-10 glass monolith with partially spalled clay and alteration phases are labeled.

In figure 2 the total mass releases of lithium and boron into solution are shown as a function of time for the replicate tests. The release of these elements is an important gauge of the glass corrosion, as they are not expected to be incorporated to a significant extent into alteration phases, nor are they present in the steel. For the first 220 weeks (170 weeks for the N3 test), the three samples had very similar release rates. Sampling resumed after a 180-week gap, whereupon it was found that the release rates followed the same trends, albeit with somewhat more scatter among the release values obtained for the triplicate samples. This divergence among the samples is likely a reflection of subtly differing reaction progress, which was noted qualitatively by optical examination of the samples at each sampling. This is discussed in greater detail later, in conjunction with the actinide release.

The release of the transuranic elements neptunium, plutonium, and americium has been monitored in both the VR and AS solutions by high-resolution alpha spectroscopy since the tests were initiated. However, uranium and thorium levels in the solutions were not measurable with the alpha spectroscopy and have only recently become available with the ICP/MS data. The release of the transuranic elements neptunium, plutonium, and americium into solution is plotted in figure 3 for the N2 and N3 test series. Neptunium is highly soluble and does not sorb substantially onto the stainless steel, and is thus expected to be released at a normalized rate similar to that of lithium and boron. The neptunium values plotted in figure 3 are based on vessel rinse data and little or no neptunium was detected in the acid strip solution. Plutonium and americium, on the other hand, are known to sorb onto the stainless steel from which the test vessel is made, and may also be incorporated into secondary phases (see, for instance, reference 6). The Pu and Am data in the figures represent a sum of the vessel rinse and acid strip results. 

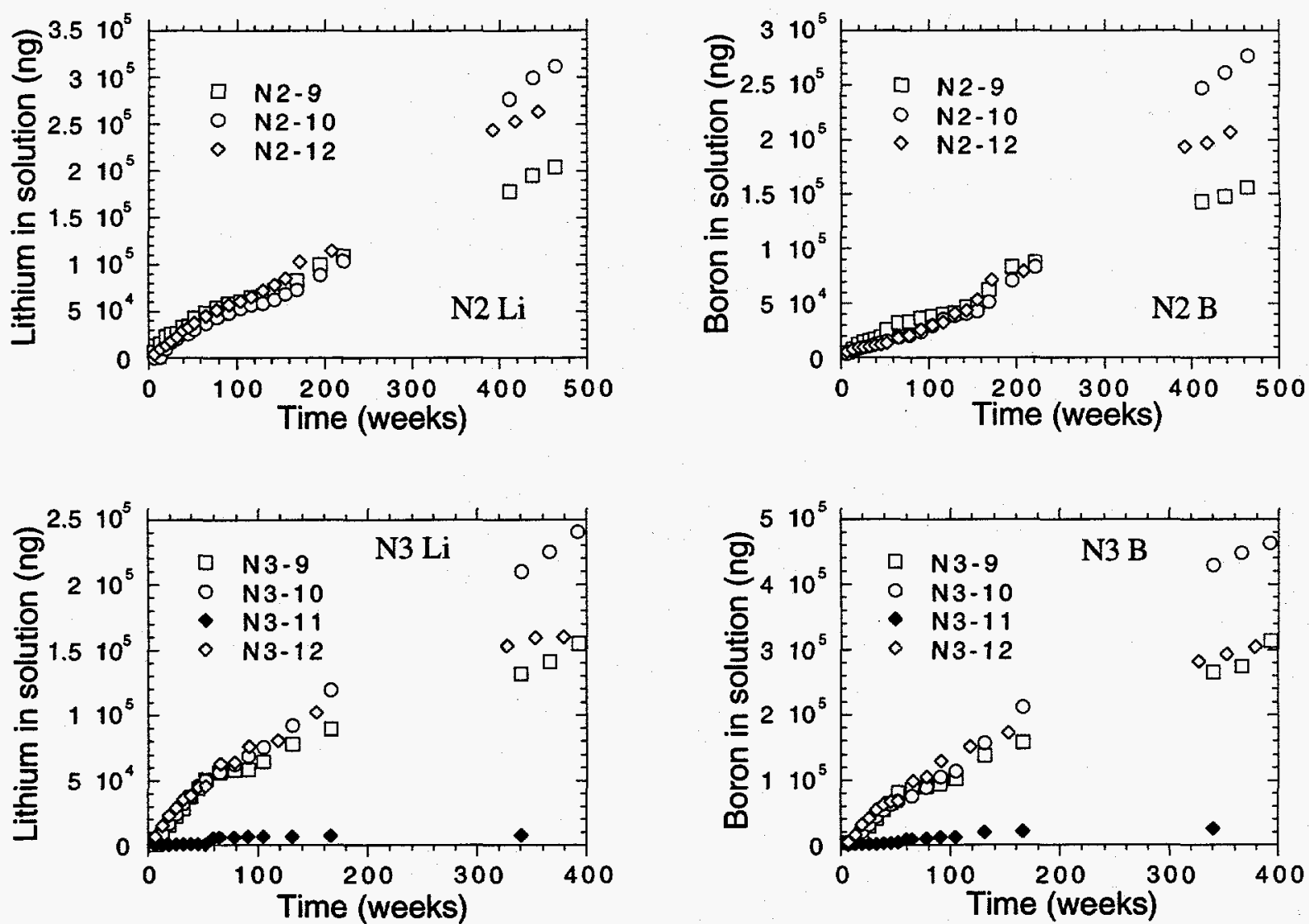

Figure 2. Cumulative release of lithium and boron from the N2 (top) and N3 (below) tests as a function of elapsed time. In each series, test numbers 9,10 , and 12 contain glass while test \#11 is a blank with no waste form. The N2\#11 results are not shown but are comparably small, as are those of N3\#11 for lithium and boron; these elements are introduced to the blank test by the injection of the EJ-13 water, but at a rate clearly far below the release rate from the glass.
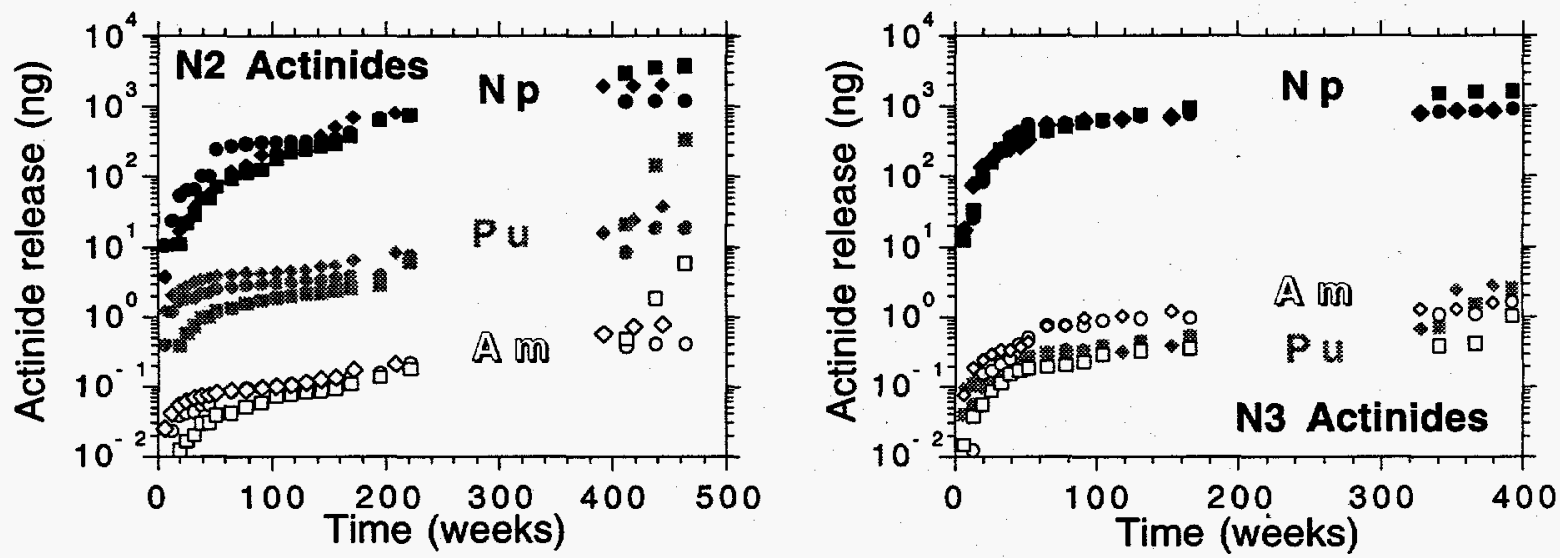

Figure 3. Cumulative release of actinides from the N2 (left) and N3 (right) tests as determined by high-resolution alpha spectroscopy. The symbols indicate individual samples, which are run in triplicate; circles are N2 (N3)-9, squares are N2 (N3)-10, and diamonds are N2 (N3)-12.

Release rates for selected elements have been calculated through the January 1995 samplings. The normalized release is $N_{i}=M /\left(c_{i} A\right)$, and the normalized release rate is $R_{i}=\Delta N_{i} / \Delta t$ where $M_{i}$ is the mass of element $i$ released from the sample, $c_{i}$ is the atomic fraction of element $i$ in the 
source glass, $\Delta t$ is the time interval between tests, and $A$ is the surface area of the glass monolith $\left(1.36 \times 10^{-3} \mathrm{~m}^{2}\right)$. The normalized release rates for some of the elements are given in Table 3 for the $\mathrm{N} 2$ and $\mathrm{N} 3$ tests. Note that the normalized release rates of boron and lithium are similar at all test times. For the N3 tests, the normalized release of uranium is typically an order of magnitude lower than those of lithium and boron, while that of thorium is lower still.

All other elements, particularly the actinides (other than neptunium), have been released at lower normalized rates than those of lithium and boron. These lower rates are due to incorporation of elements into alteration phases, the clay layer, or sorption onto the stainless steel retainer. As a result, these elements remain attached to the waste package assemblage $[1,3-6]$. The spalling of these phases from the glass is then what controls the release of the incorporated elements to solution. These spalled-off phases may then become suspended in solution as colloids. Alternatively, they may settle out of solution, re-dissolve into solution, or sorb onto the stainless steel test vessel. The jumps in plutonium and americium release rates seen in some of the latest data indicate that some actinide-bearing secondary phases are spalling off of the glass and appearing in the test solution. These measurements are consistent with the visual observations, where the N2-10 test showed the greatest corrosion of the metal and spalling of clay from the glass into the test solution of the N2 series tests, and N3-12 glass and metal appeared the most reacted from the N3 series. Note that the neptunium release does not jump like those of plutonium and americium but continues smoothly as do the lithium and boron releases. This is consistent with the clay alteration layer being depleted in these elements; their release is thus unaffected by the spalling of the clay. Continued spalling of the clay will ultimately cause the normalized release of plutonium and americium (as solution-borne solid phases) to approach that of the lithium and boron. The role of colloidal solids in solution is also reflected in the sequential filtering data, where substantial plutonium and americium often appear on the filters and are removed from the filtered solution.

Table 3. Normalized release rates for $\mathrm{Li}, \mathrm{B}$, and $\mathrm{Th}$, and $\mathrm{U}$ from the $\mathrm{N} 2$ and $\mathrm{N} 3$ series averaged over the three samples in each test for last 250 weeks of testing.

\begin{tabular}{ccccc}
\hline & \multicolumn{4}{c}{ Normalized Release Rates $\left(\mathrm{gm} / \mathrm{m}^{2} /\right.$ day $)$} \\
\hline Test Series & $\mathrm{Li}$ & $\mathrm{B}$ & $\mathrm{Th}^{*}$ & $\mathrm{U}^{*}$ \\
$\mathrm{~N}-2$ & $3.4 \times 10^{-3}$ & $2.3 \times 10^{-3}$ & - & $1.4 \times 10^{-3}$ \\
$\mathrm{~N}-3$ & $3.8 \times 10^{-3}$ & $3.8 \times 10^{-3}$ & $1.06 \times 10^{-5}$ & $3.9 \times 10^{-4}$ \\
\hline * uranium and thorium data averaged over the last 78 weeks of testing only.
\end{tabular}

\section{Colloidal Particle Analyses}

AEM examination of colloidal material from the N3-9 solution sampled January 12, 1995 revealed a small particle of a calcium-thorium-phosphate mineral phase embedded in smectite-type clay that appears to have spalled off of the glass (figure 4). This mineral was identified by composition and electron diffraction as brockite. Brockite is a member of the rhabdophane group and is structurally similar to members of the monazite mineral group. Interestingly, monazite minerals themselves have been considered as crystalline waste forms for disposal of low-level radioactive waste[7]. Brockite is known to incorporate rare earth elements (La, $\mathrm{Ce}, \mathrm{Nd}$ ) and uranium $[5,8]$, as well as americium and possibly plutonium [6] into its crystal structure. Its appearance as a secondary phase may explain the low initial release rates of actinides from the N3 tests. Brockite has been found to be ubiquitous on the surfaces of the ATM-10 glass reacted for up to one year in the N3 tests (see also figure 4). The sudden jump in release rates correlates qualitatively with this material spalling off of the glass as reaction progresses. Examination of colloidal material from the $\mathrm{N} 2$ tests has thus far not identified a prominent actinide-bearing secondary phase, nor was any such phase identified in large quantities on the SRL 165 surfaces after one year of reaction progress [1].

In both the $\mathrm{N} 2$ and $\mathrm{N} 3$ tests, the majority of colloid particles observed by AEM have been either a smectite-type clay or a variety of iron silicates (the iron silicates resulting largely from enhanced corrosion at the container/glass interfaces [1,5]). In the N2 tests, both the clay and iron 

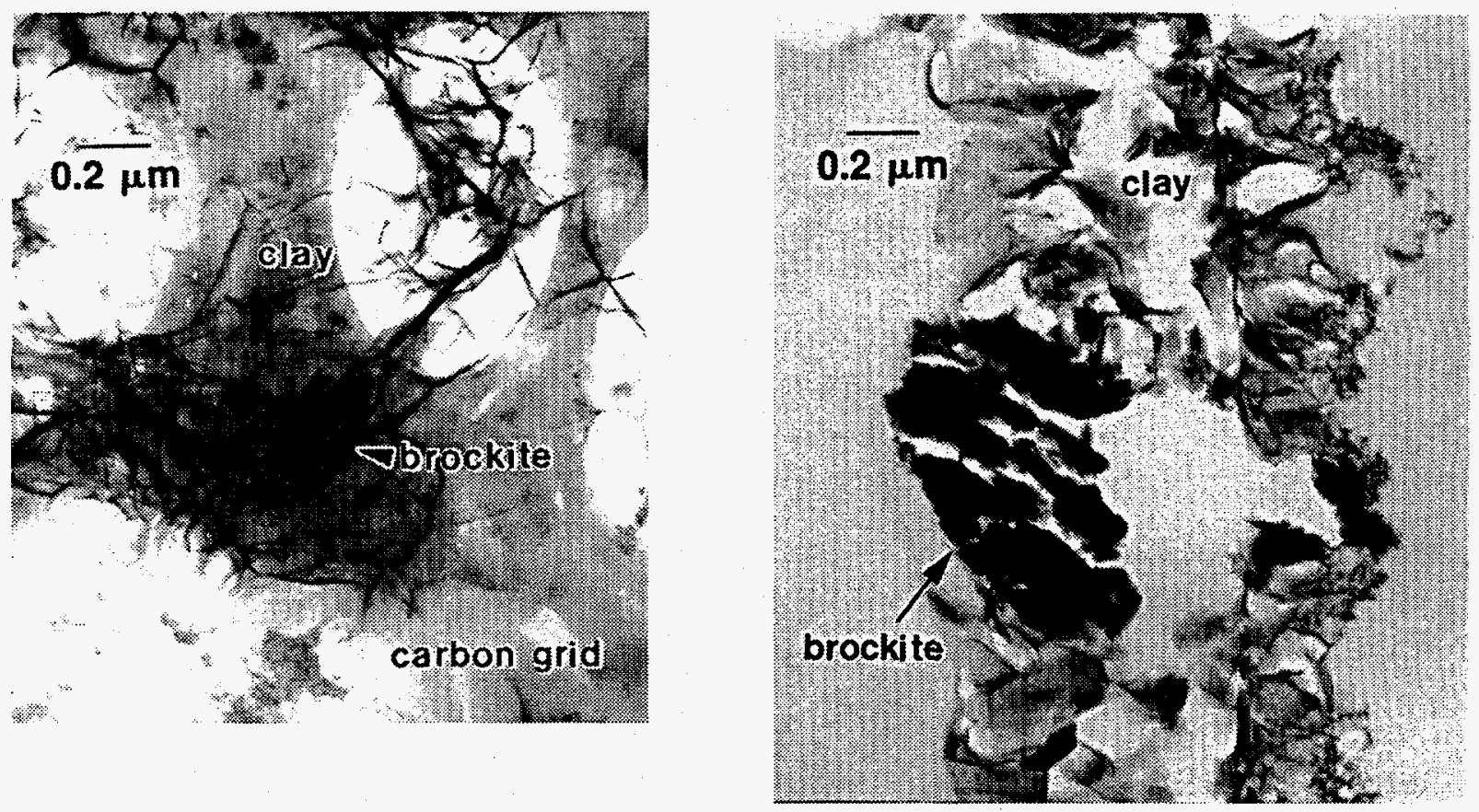

Figure 4. At left is an AEM micrograph of a brockite particle found attached to a clay colloid in the leachate solution from the N3 Test series after nearly 8 years of testing. At right is an AEM micrograph of brockite and clay reaction layer from the top surface of the N3\#8 glass monolith after reacting for 1 year. The brockite particles appear to grow larger with time, although continuous nucleation may provide a steady supply of the smaller particles found in the colloids.

silicates frequently contain small amounts of uranium. Uranium is also found on occasion in the clays and iron silicates from the N3 tests; interestingly, thorium has not been detected in the clay.

\section{CONCLUSIONS}

The behavior of two model vitreous waste forms has been examined over extended periods in tests designed to simulate repository conditions where water breaches the waste form container. The release of the bulk glass components lithium and boron has been found to set an upper limit on the release of other elements, as lithium and boron tend to remain dissolved in solution and are unlikely to be incorporated into alteration phases. Also, the development of alteration phases is found to depend on glass composition. The alteration phases may incorporate actinide elements, retarding their initial release; however, mechanical spalling of the reacted layer in the repository can release these materials as colloids and may eventually result in nearly congruent release of all the elements.

\section{ACKNOWLEGMENTS}

This work was performed under contract to the Yucca Mountain Site Characterization Project sponsored by the DOE Office of Civilian Radioactive Waste Management at the Lawrence Livermore National Laboratory (contract number W-7405-ENG-48) and Argonne National Laboratory under contract W-31-109-ENG-38.

\section{REFERENCES}

1. J. K. Bates and T. J. Gerding, Application of the NNWSI Unsaturated Test Method to Actinide Doped SRL 165 Type Glass, Argonne National Laboratory Report ANL-89/24 (1990). 
2. G. D. Maupin, W. M. Bowen and J. L. Daniel, "Fabrication and Characterization of MCC Approved Testing Material- ATM-10 Glass, "Pacific Northwest Laboratory PNL-5577-10 (1988).

3. J. K. Bates and E. C. Buck, Proceedings of the 1994 International High-Level Radioactive Waste Management Conference, American Nuclear Society (1994).

4. J. K. Bates et al., Yucca Mountain Project- Argonne National Laboratory Annual Progress Report, FY 1994, Argonne National Laboratory Report ANL-94/42 (1994).

5. J. A. Fortner, T. J. Gerding, and J. K. Bates, "Long-Term Test Results from a West Valley Actinide-Doped Reference Glass," Proc. Am. Ceramic Soc. (1995, in press).

6. J. K. Bates, J. P. Bradley, A. Teetsov, C. R. Bradley, and M. Buchholtz ten Brink, Science 256, 649 (1992).

7. G. J. McCarthy, W. B. White, and D. Pfoertsch, Mat. Res. Bull. 13, 1239 (1978).

8. J. L. Fisher and D. S. Meyrowitz, Am. Mineral. 47, 1364 (1962). 


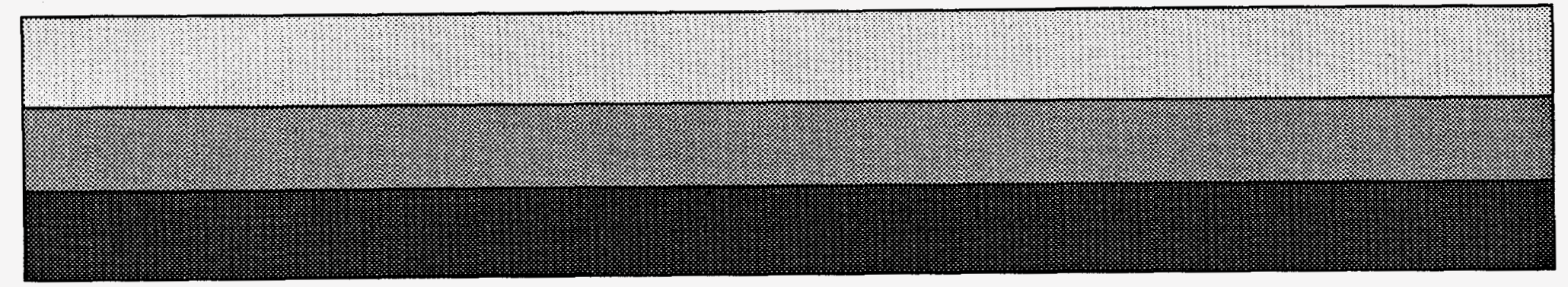

